\title{
Local variability in growth and reproduction of Salix arctica in the High Arctic
}

\author{
Noémie Boulanger-Lapointe, ${ }^{1,2}$ Esther Lévesque, ${ }^{1,2}$ Claudia Baittinger ${ }^{3}$ \& Niels M. Schmidt ${ }^{4,5}$ \\ ${ }^{1}$ Department of Environmental Sciences, Université du Québec à Trois-Rivières, 3351 boul. des Forges, C.P. 500, Trois-Rivières, Quebec G9A 5H7, \\ Canada \\ ${ }^{2}$ Center for Northern Studies, Université Laval, 2405 rue de la Terrasse, Québec G1V 0A6, Canada \\ ${ }^{3}$ Environmental Archaeology and Materials Science, National Museum of Denmark, Frederiksholms Kanal 12, DK-1220 Copenhagen, Denmark \\ ${ }^{4}$ Department of Bioscience, Aarhus University, Frederiksborgvej 399, DK-4000 Roskilde, Denmark \\ ${ }^{5}$ Arctic Research Centre, Aarhus University, C.F. Møllers Allé 8, DK-8000 Aarhus C, Denmark
}

\section{Keywords}

Herbivory; nutrient; plant colonization;

vegetation; shrub; water availability.

\section{Correspondence}

Noémie Boulanger-Lapointe, Department of Geography, University of British Columbia, 1984 West Mall, Vancouver, British Columbia V6T 1Z4, Canada. E-mail: noemie.boulanger-lapointe@geog.ubc.ca

\begin{abstract}
Arctic terrestrial ecosystems are heterogeneous because of the strong influences of microtopography, soil moisture and snow accumulation on vegetation distribution. The interaction between local biotic and abiotic factors and global climate patterns will influence species responses to climate change. Salix arctica (Arctic willow) is a structuring species, ubiquitous and widespread, and as such is one of the most important shrub species in the High Arctic. In this study, we measured $S$. arctica reproductive effort, early establishment, survival and growth in the Zackenberg valley, north-east Greenland. We sampled four plant communities that varied with respect to snow conditions, soil moisture, nutrient content and plant composition. We found large variability in reproductive effort and success with total catkin density ranging from 0.6 to 66 catkins $/ \mathrm{m}^{2}$ and seedling density from $<1$ to 101 seedlings $/ \mathrm{m}^{2}$. There were also major differences in crown area increment $\left(4-23 \mathrm{~cm}^{2} /\right.$ year) and stem radial growth (40-74 $\mu \mathrm{m} /$ year). The snowbed community, which experienced a recent reduction in snow cover, supported young populations with high reproductive effort, establishment and growth. Soil nutrient content and herbivore activity apparently did not strongly constrain plant reproduction and growth, but competition by Cassiope tetragona and low soil moisture may inhibit performance. Our results show that local environmental factors, such as snow accumulation, have a significant impact on tundra plant response to climate change and will affect the understanding of regional vegetation response to climate change.
\end{abstract}

To access the supplementary material for this article, please see the supplementary files under Article Tools, online.
Vegetation productivity and cover are predicted to increase in the Arctic under global climate change scenarios (Hassol 2004; Stocker et al. 2013). Changes in temperature and precipitation will affect plant reproduction and growth, and ultimately alter community composition and species distribution (Walker et al. 2006; Elmendorf, Henry, Hollister, Björk, Bjorkman et al. 2012; Elmendorf, Henry, Hollister, Björk, Boulanger-Lapointe et al. 2012). Expansion will, however, be non-linear and affected by topographical and moisture gradients as well as biotic interactions (Shaver et al. 1996; Ropars \& Boudreau 2012). Shrubs are expected to drive those changes as they respond positively to warming temperature under both natural and experimental conditions (Forbes et al. 2010; Elmendorf, Henry, Hollister, Björk, Bjorkman et al. 2012; Myers-Smith, Elmendorf et al. 2015) and have increased in cover in many locations, especially in the Low Arctic (Sturm et al. 2001; Forbes et al. 2010; 


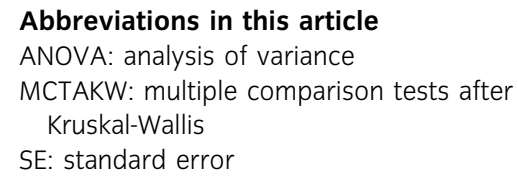

Myers-Smith et al. 2011; Tremblay et al. 2012). Knowledge of shrub species performance associated with local biotic and abiotic factors will provide timely information to understand mechanisms of change and predict potential contribution of woody species to Arctic tundra vegetation from the plot to the regional scale (Douhovnikoff et al. 2010).

High-Arctic landscapes are heterogeneous, varying from spatially restricted wetlands with full plant cover to polar deserts (Bliss \& Svoboda 1984). Local heterogeneity is a result of small differences in topography that affects the distribution of snow and soil moisture, and hence, soil nutrient availability (Spadavecchia et al. 2008; le Roux \& Luoto 2014). Numerous studies highlight the importance of biotic interactions on current community composition and response to global climate changes. Plant-plant interactions, such as facilitation (Carlsson $\delta$ Callaghan 1991) and competition for nutrients (Chapin et al. 1995; Gold \& Bliss 1995), water and/or light (Pajunen et al. 2011), have been shown to drive plant community composition in low-energy systems (le Roux et al. 2013). Exclosure experiments have shown that grazing by large and small mammals affect plant recruitment and growth in many regions (Cooper 2006; Olofsson et al. 2009; Olofsson et al. 2014; Falk et al. 2015). While plantplant and plant-herbivore interactions may be prevalent in one system or another (Chapin et al. 1989; Post \& Pedersen 2008), recent modelling studies indicate that synergistic interactions of these factors can mediate climate change effects across the food web (Bêty et al. 2014; Farrer et al. 2014).

Vegetation monitoring begun at Zackenberg, in HighArctic Greenland, in 1997 and ongoing has shown substantial change in cover and community structure of certain plant communities but resistance to such conditions in others (Schmidt, Kristensen et al. 2012). Most changes were observed in the fen and the grassland and were related to drier conditions caused by less snow and deeper active layer in recent years. The four shrub species in the area, Cassiope tetragona, Salix arctica, Dryas sp. and Vaccinium uliginosum, present opposing trends in cover with a general decrease in C. tetragona and V. uliginosum and some increase in cover of Salix arctica and Dryas sp. Weak response of shrub species in the region may partly be associated with grazing by muskox, the only large herbivore in the study area (Forchhammer et al. 2005; Schmidt et al. 2015). Stable isotope analysis on faeces and hairs from the local population showed that their summer diet was composed of $22-35 \%$ S. arctica leaves and young catkins (Kristensen et al. 2011 ). However, Tolvanen et al. (2002) also demonstrated that $S$. arctica survived muskox grazing by increasing the production of shoots from dormant buds. The Arctic willow is the most common and ubiquitous shrub species in the region and little is known about its population dynamics. Population size structure in the fell-field suggests that there is frequent recruitment by seed (BoulangerLapointe et al. 2014), but difference in species performance across habitat type is poorly known.

Colonization by the Arctic willow has been closely associated with water supply from snowdrifts, and turf hummock formation (Raup 1963). Raup (1963) found that under a warming climate, snow banks will decrease in volume, turf hummocks will become drier and willow mortality will increase. Results from experimental warming in subalpine heath indicate that seedling establishment is negatively affected by increased temperature unless water is also added to the system (Shevtsova et al. 2009). In the High Arctic, the species' reproductive effort and success generally respond positively to experimental warming (Klady et al. 2011) and spring snow cover has a consistent negative effect on S. arctica growth (Schmidt et al. 2010), but the amplitude of both responses varies according to plant community type. When measured along a natural temperature gradient at Zackenberg, the species secondary growth was positively correlated with temperature while apical growth showed the opposite trend (Campioli et al. 2012). Difference in response between habitat types has been linked to the species' high phenotypic plasticity; notably, differences in net photosynthesis rate have been attributed to sex and local environmental conditions (Jones et al. 1999).

In this study, we investigated the range of responses of $S$. arctica growth and reproduction to environmental factors in the Zackenberg valley lowland, Greenland. To compare indicators of plant performance in different plant communities, we selected two populations located in productive plant communities with a continuous cover of vegetation, and two populations with lower productivity and plant cover. Plant performance was evaluated through indicators of plant reproductive effort, success of establishment, as well as crown area increment and stem radial growth. Following results from previous studies conducted at Zackenberg (Schmidt et al. 2010; Schmidt et al. 2012; Boulanger-Lapointe et al. 2014), we hypothesize that moisture availability is the main factor affecting $S$. arctica growth and reproductive success. Additionally, we expect that to a lesser extent, biotic interactions (plant-plant and animal-plant) will modulate species performance. 


\section{Material and methods}

\section{Study species}

Salix arctica Pall. is one of the few and most widespread shrub species in the High Arctic (Porsild 1957). Its tolerance of a wide range in parameters including moisture, temperature, nutrient levels and snow cover and its high phenotypic plasticity (Porsild \& Cody 1980; Jones et al. 1999; Aiken et al. 2007), as well as long-distance dispersal and establishment by seeds (Steltzer et al. 2008) make it a potential driver of shrub expansion in the region. Salix arctica seeds are dispersed in the autumn and conditionally dormant; germination can occur immediately after dispersal if temperature and moisture requirements for germination are met, but the temperatures needed for germination are lowered with cold stratification (Densmore \& Zasada 1983). Germination rates of seeds from the High Arctic under controlled conditions vary greatly, ranging from $2 \%$ to $8 \%$ (Dawson 8 Bliss 1989 ) to $63-94 \%$ (Jones 1995). Clonal growth also contributes to the species propagation and is achieved through the formation of adventitious roots on low branches (Aiken et al. 2007). In the Zackenberg valley, an area extending from sea level to $600 \mathrm{~m}$ a.s.l., S. arctica is present in all plant communities, except the salt marsh, and it is dominant in the snowbed and fell-field community (Bay 1998).

\section{Study site}

The study was conducted in vegetation types characteristic of the Zackenberg valley in north-east Greenland $\left(74^{\circ} 30^{\prime} \mathrm{N} 21^{\circ} 30^{\prime} \mathrm{W}\right)$. The region has a mean air temperature of $5^{\circ} \mathrm{C}$ and a mean precipitation of $12 \mathrm{~mm}$ during the snow-free period: June, July and August in 1996-2010 (Boulanger-Lapointe et al. 2014). A significant annual warming of $0.25^{\circ} \mathrm{C}$ has been measured for the period 1991-2005 together with a general diminution in snow cover (Hansen et al. 2008; Hinkler et al. 2008). The decline in snow cover may be attributed to a decline in winter precipitation as well as an increase in spring temperature, although these changes do not yet show significant trends (Jensen et al. 2014). The study area has great interannual variability in the end-of-winter snow accumulation but not in the pattern of snow distribution (Buus-Hinkler et al. 2006). The depletion of the snow cover is typical of mountainous areas with snow accumulating in depressions and remaining longer at higher elevations (Hinkler et al. 2008). Sites were chosen according to the occurrence of $S$. arctica, the diversity of environmental conditions and availability of data from previous and ongoing monitoring in those same plant communities at Zackenberg (Bay 1998; Schmidt, Hansen et al. 2010; Schmidt et al. 2012). Sampling areas were all located within a $5 \mathrm{~km}$ radius in the valley (Fig. 1). We sampled four plant communities along an altitudinal gradient with varying levels of snow accumulation: (1) a snowbed community (ca. $15 \mathrm{~m}$ a.s.l.), largely dominated by $S$. arctica and occurring where late-lying snow patches form on the south-facing slope of Aucellabjerg; (2) an abrasion plateau (ca. $31 \mathrm{~m}$ a.s.l.), a barren community with little snow cover and subject to strong wind effects; (3) a dwarf-shrub heath (ca. $36 \mathrm{~m}$ a.s.l.) dominated by Cassiope tetragona, with intermediate levels of snow accumulation and ground covered by small hummocks; and (4) a fell-field (ca. $433 \mathrm{~m}$ a.s.l.), a barren community

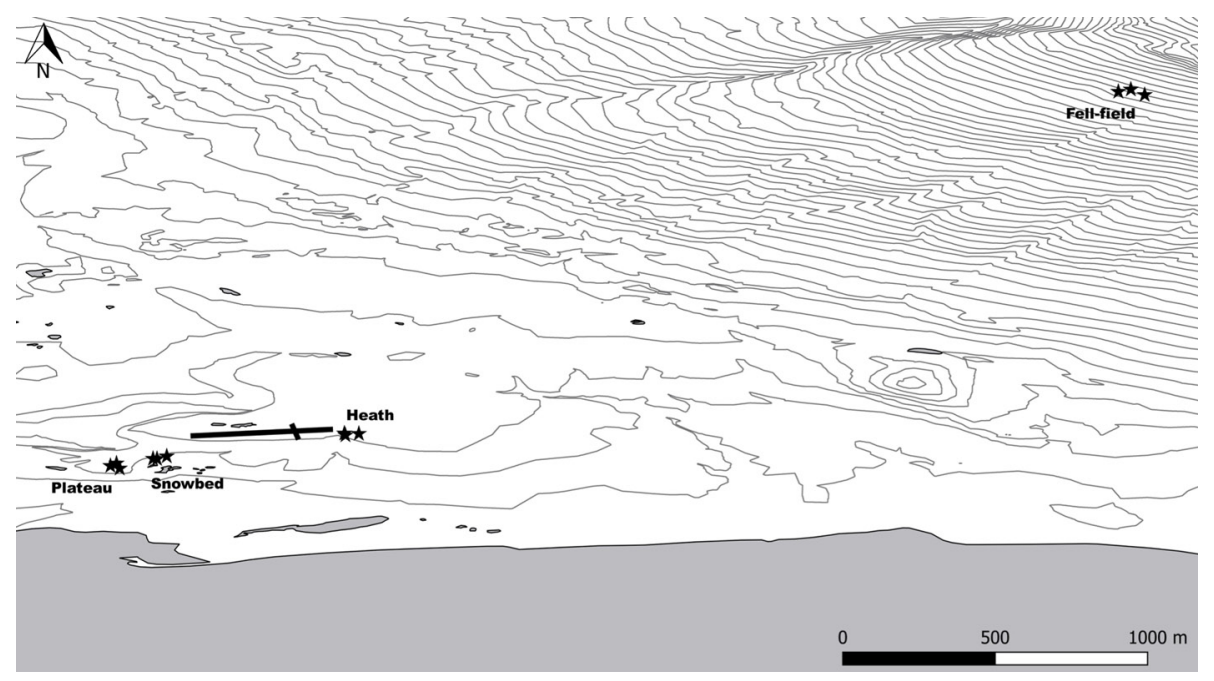

Fig. 1 Topographical map of the Zackenberg valley with contour lines at $10 \mathrm{~m}$ intervals showing the locations of the study sites. 
with very little snow accumulation (Bay 1998; Schmidt et al. 2010).

\section{Field sampling}

Soil nutrient and moisture content data were available from a previous study conducted in the plateau, the snowbed and the heath in 2005 (Schmidt et al. 2010). To obtain comparable soil data in the fell-field, we conducted complementary field measurements in 2010, following Schmidt et al. (2010). Nutrient supply rates were estimated using in situ burials of $\mathrm{PRS}^{\mathrm{TM}}$-probes (Western Ag Innovations). In 2005, probes were buried for 43 days from 29 June to 11 August, and for 58 days in 2010 from 12 June to 8 August. At each site, two cation and two anion probes were inserted vertically into the soil (ca. $10 \mathrm{~cm}$ ) about $50 \mathrm{~cm}$ from 7 (in 2005) and 10 (in 2010) S. arctica individuals. Upon recovery, probes were processed by Western Ag Innovations following standard procedures. Estimates of nutrient availability were obtained for the following elements: total $\mathrm{N}, \mathrm{NO}_{3}-\mathrm{N}$, $\mathrm{NH}_{4}-\mathrm{N}, \mathrm{Ca}, \mathrm{Mg}, \mathrm{K}, \mathrm{P}, \mathrm{Fe}, \mathrm{Mn}, \mathrm{Cu}, \mathrm{Zn}, \mathrm{B}, \mathrm{S}$, and $\mathrm{Al}$. Soil moisture in the uppermost $5 \mathrm{~cm}$ was measured at 28 random locations within each site in 2005 and 2010 on burial and removal date of the $\mathrm{PRS}^{\mathrm{TM}}$-probes using a ThetaProbe ML2X sensor (Delta-T Devices Ltd.) after three days without precipitation.

Vegetation sampling and measurements were conducted in three $100 \mathrm{~m}^{2}(10 \mathrm{~m} \times 10 \mathrm{~m})$ random plots in each of the plant communities (plateau, snowbed, heath and fell-field) in 2010. Vegetation cover was assessed from 10 randomly placed $70 \mathrm{~cm} \times 70 \mathrm{~cm}$ quadrats in each of the plots using modified Domin-Krajina cover classes (Lévesque 1996). Mid-class values were used to evaluate average species cover. Species names follow Porsild (1957) and were validated using the Integrated Taxonomic Information System (retrieved January 2012, www.itis.gov). Seedling (individuals with a total cover of $<0.25 \mathrm{~cm}^{2}$ ) and male and female catkin density were surveyed over the entire area of each plot $\left(100 \mathrm{~m}^{2}\right)$ in the fell-field and the plateau. In the snowbed and the heath, male and female catkin density was determined in the random quadrats $(70 \mathrm{~cm} \times 70 \mathrm{~cm})$ used for vegetation cover measurements, while seedling density was measured in 10 randomly placed $25 \mathrm{~cm} \times 25 \mathrm{~cm}$ quadrats per plot. Size of sampling area was reduced in those two communities because of time constraints associated with high seedling and catkin densities. All data were standardized to square metre for analyses. Seedlings were categorized into three age classes following observation of bud scars along the stems: newly established (0), one year old (1), or $\geq$ two years old (2) (Fig. 2); each scar

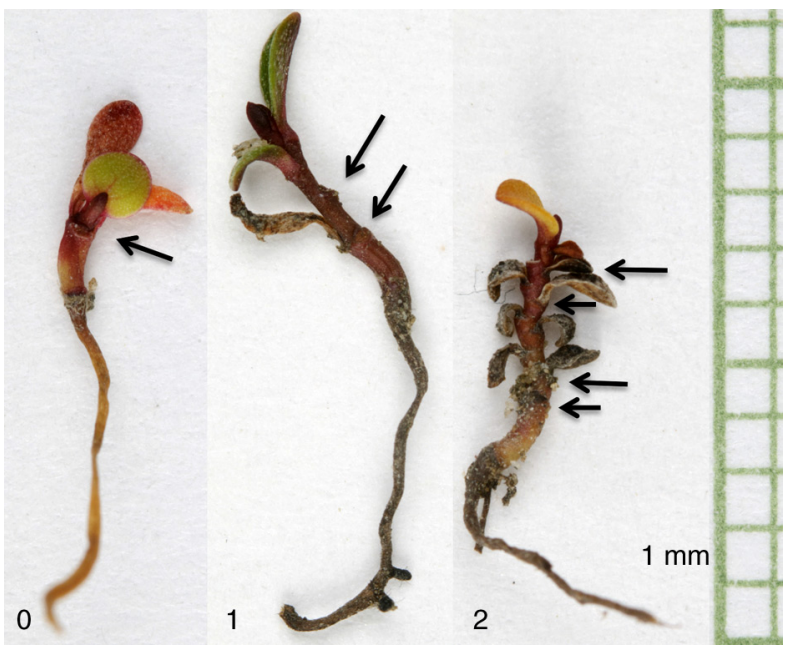

Fig. 2 Salix arctica seedlings collected in 2009 at Zackenberg and sorted by age classes: (0) newly established, (1) one year old and (2) two years old or more. Age classes correspond to those in Table 1.

except the first (cotyledons) corresponding to one year of growth. No more than three age classes could be distinguished because the proximity of scars after two years prevented accurate dating in the field. In the barren communities (plateau and fell-field), the crown size of each established individual $\left(>0.25 \mathrm{~cm}^{2}\right)$ was measured along two perpendicular axes. When collecting specimens, we verified the composition of a "clump" and in most case ( $>80 \%$ of the time) confirmed that it was one individual established by seed. For the remaining $20 \%$ of the samples, mainly composed of larger crown sizes, two or three individuals were sometimes intermingled resulting in a slight overestimation of individual crown area. In the productive communities (snowbed and heath) only individuals sampled for radial growth were measured because stems were always intermingled and could not be identified without removal.

\section{Dendrochronological analyses}

After completing all field measurements, 15-30 individual plants with a root collar $>1 \mathrm{~cm}$ diameter were measured for crown area and collected at each site. Individuals across a range of plant sizes were chosen within the site area. For minimal age determination, samples were boiled and thin sections $(15-20 \mu \mathrm{m})$ of the root collar were cut with a microtome. The sections were then stained with a solution of $0.1 \%$ safranin, $0.1 \%$ alcian blue and $50 \%$ ethanol, and subsequently mounted on slides using a low viscosity-mounting medium. When dried, slides were digitally scanned (Nikon Super CoolScan 8000 ED, 4000 dpi; Fig. 3). Growth rings were counted on the pictures 


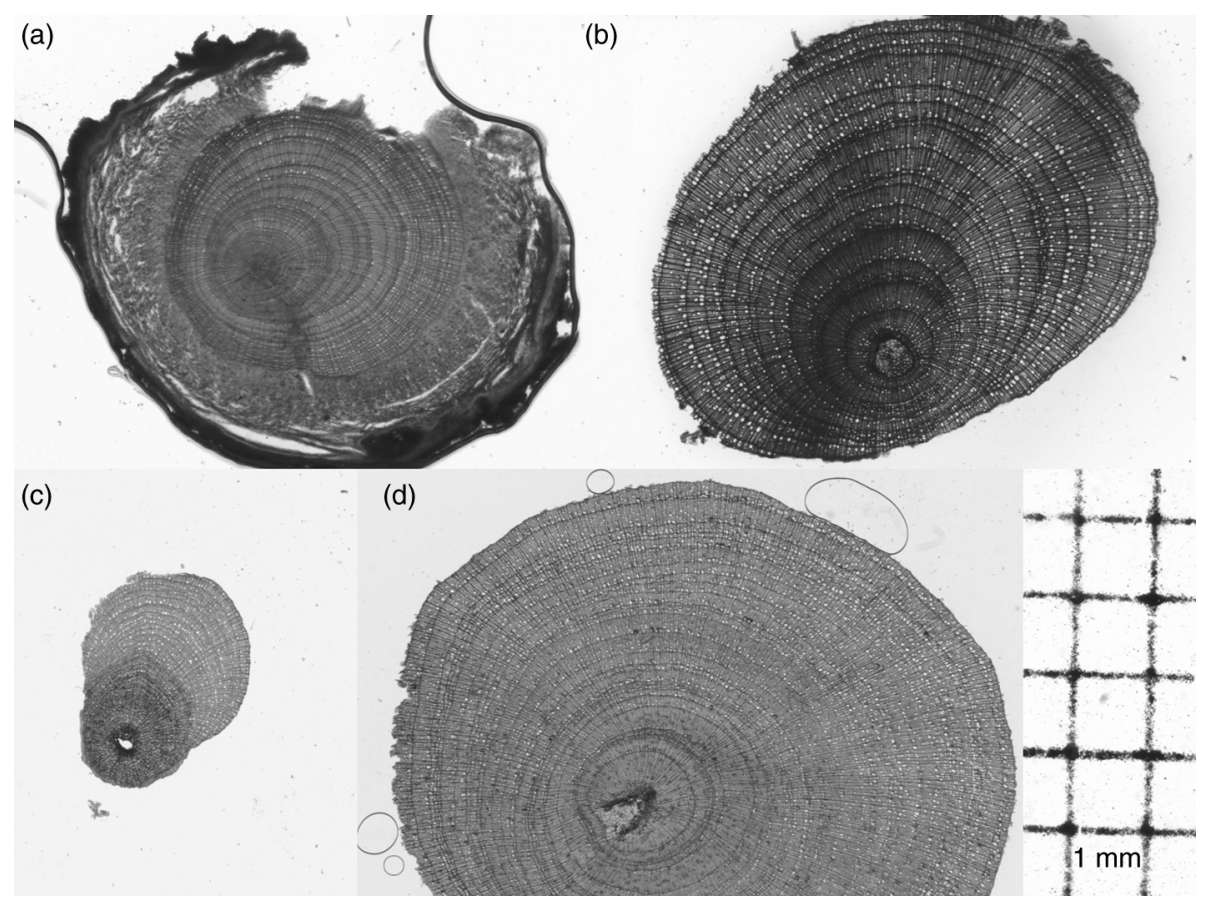

Fig. 3 Thin sections from the wood samples collected on (a) the plateau, (b) the snowbed, (c) the heath and (d) the fell-field.

using an image analysis program (Adobe Photoshop) and total diameter was measured on two radii positioned at $90^{\circ}$ (Lignovision $^{\mathrm{TM}}$ software from RINNTECH, 2001-04). Samples were excluded if the cut was not strictly perpendicular to the vessels or if incomplete sectioning did not enable the measurement of two perpendicular radii. Mean annual stem radial growth was calculated from the radius length divided by the number of rings (i.e., minimal age). Crossdating was deemed to be beyond the scope of this study. While it may have marginally increased dating accuracy of older individuals, we required a consistent time efficient method appropriate for all samples. Mean crown area increment was estimated from the crown area divided by the number of growth rings.

\section{Statistical analysis}

Inter-site differences in mean crown area increment, radial growth, total density of catkins, density of seedlings, seedling survivorship, soil moisture and, soil $\mathrm{N}$ and P were tested with a Kruskal-Wallis test for unbalanced design (i.e., varying number of replicates for each factor). MCTAKW were used to assess which pairs of sites were significantly different (Giraudoux 2013). Inter-site differences in plant cover were tested using a one-way ANOVA and a Tukey Honest significant difference test. Differences in the number of male and female catkins within each site were tested using a paired Students $t$-test.
Statistical analyses were performed using $\mathrm{R}$ software (R Core Team 2014).

\section{Results}

Soil moisture assumed to decrease with increasing elevation except on the plateau, where snow melts early and vegetation does not benefit from water seepage (Elberling et al. 2008; Fig. 4, Supplementary Table S1). Soil moisture values reflect the combined influence of winter snow depth and the rate of snowmelt (Tamstorf et al. 2007; Gacitua et al. 2013; Supplementary Table S1). There was no significant variation in nutrient concentrations except for high $\mathrm{N}$ concentrations on the plateau (Fig. 4, Supplementary Table S1). Total plant cover ranged from $1 \%$ to $74 \%$ and Salix arctica cover from $<1 \%$ to $58 \%$ (Fig. 3, Supplementary Table S2). Salix arctica dominated in the snowbed and the fell-field, and co-dominated with Cassiope tetragona in the heath and with Dryas sp. on the abrasion plateau (Supplementary Table S2). Average catkin density ranged from 0.6 $(\mathrm{SE}=0.4)$ catkins $/ \mathrm{m}^{2}$ on the plateau to $23 \quad(\mathrm{SE}=16)$ catkins $/ \mathrm{m}^{2}$ in the snowbed, but only the plateau and the snowbed were significantly different (Fig. 4). The density of female and male catkins within sites was not significantly different (paired Students $t$-test, $P>0.05$ ). Seedling density in the field varied from almost zero on the plateau to over 100 seedlings $/ \mathrm{m}^{2}$ in the snowbed, 

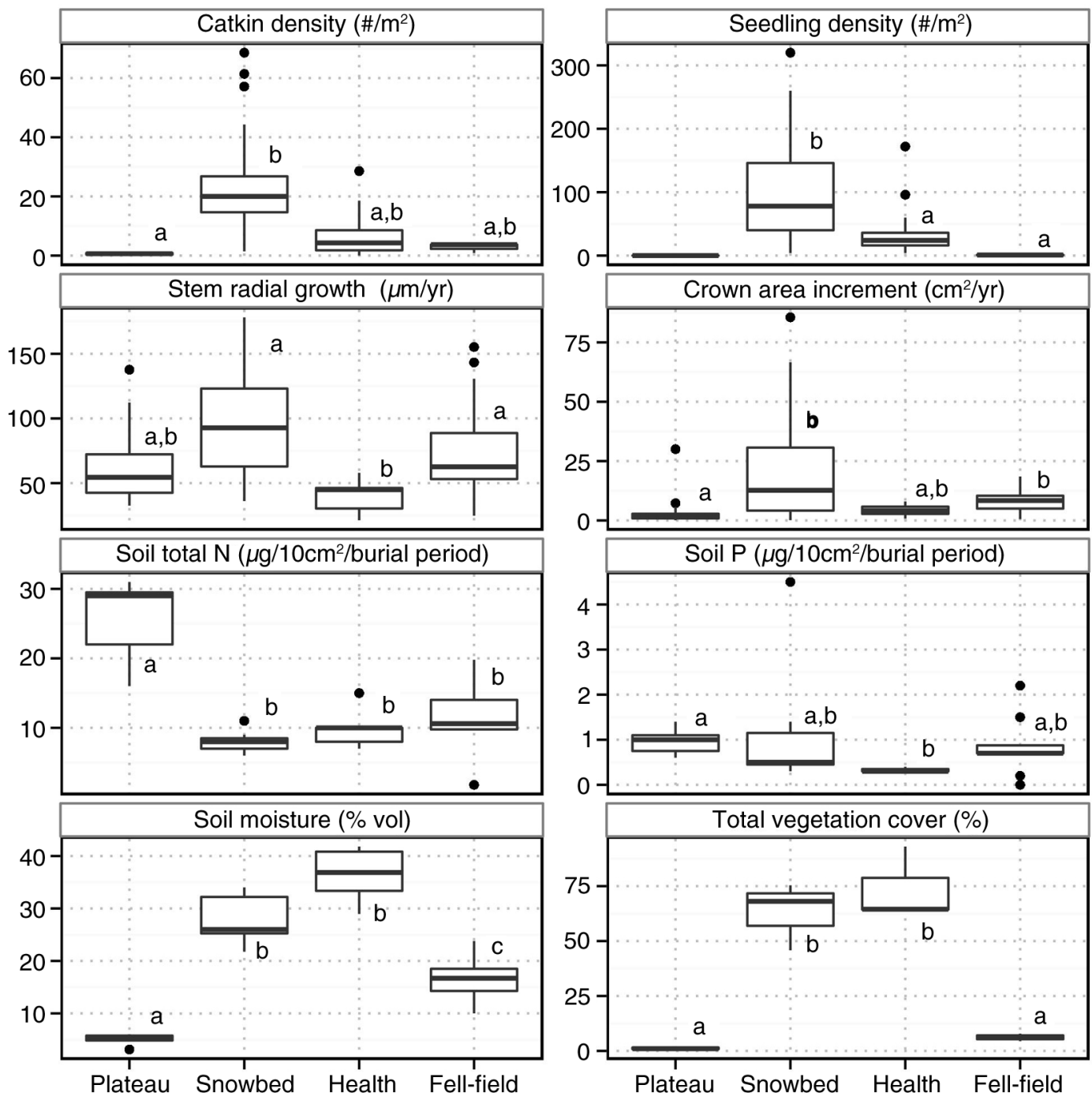

Fig. 4 Total catkin density $\left(\# / \mathrm{m}^{2}\right)$, seedling density $\left(\# / \mathrm{m}^{2}\right)$, stem radial growth ( $\left.\mu \mathrm{m} / \mathrm{year}\right)$, crown area increment ( $\mathrm{cm}^{2} /$ year), soil moisture $(\%$ vol), soil total $\mathrm{N}$ and $P\left(\mu g / 10 \mathrm{~cm}^{2} /\right.$ burial period) and total vegetation cover in four plant communities at Zackenberg, Greenland. Different letters indicate significant differences between sites (MCTAKW, $P<0.05$; Tukey HSD, $P<0.05$ ). Sampling size varies per variable and plant community measured, for catkins and seedling density: P: $n=3, \mathrm{~S}: n=30, \mathrm{H}: n=30, \mathrm{~F}: n=3$; stem radial growth: P: $n=18, \mathrm{~S}: n=19, \mathrm{H}: n=13, \mathrm{~F}: n=31$; crown area increment: P: $n=21, \mathrm{~S}$ : $n=20, \mathrm{H}: n=12$, F: $n=22$; Soil N and P: P, S and H: $n=7, \mathrm{~F}: n=10$; soil moisture: $n=28 /$ plant community; total vegetation cover: $n=3 /$ plant community.

hence only the snowbed was significantly different (Fig. 4). Survivorship in the first year, calculated as the ratio of seedling density in the one-year-old age class (1) to seedling density in the current year age class (0) for each plant communities, was $2-18 \%$, suggesting that most seedlings did not survive the first year (Table 1). There was no significant difference in survival between plant communities (MCTAKW, $P>0.05$ ).

Table 1 Salix arctica seedling density (\#/ $\mathrm{m}^{2}$; total and per age class) and associated standard error in four plant communities at Zackenberg, northeast Greenland, in 2010. Age classes are defined in Fig. 1. Superscript letters indicate significant differences within a row for total seedling density (MCTAKW, $P<0.05)$. Symbols * and ${ }^{\dagger}$ indicate significant difference in seedling density among age classes (MCTAKW, $P<0.05$ ).

\begin{tabular}{|c|c|c|c|c|c|}
\hline Plant communities & & Plateau & Snowbed & Heath & Fell-field \\
\hline Total seedling density $\left(\# / \mathrm{m}^{2}\right)$ & & Trace & $101(79)^{a}$ & $26(19)^{b}$ & $1(0.5)^{b}$ \\
\hline \multirow[t]{3}{*}{ Seedling density per age class $\left(\# / \mathrm{m}^{2}\right)$} & 0 & 0 & $87(76)^{*}$ & $14(13)^{*}$ & $0.8(0.5)^{\star}$ \\
\hline & 1 & 0 & $7(7)^{\dagger}$ & $3(3)^{\dagger}$ & $<1^{\dagger}$ \\
\hline & 2 & $<1$ & $7(6)^{\dagger}$ & $9(8)^{\dagger}$ & $<1^{\dagger}$ \\
\hline
\end{tabular}


Mean crown area increment ranged from $0.10 \mathrm{~cm}^{2} /$ year to $85.6 \mathrm{~cm}^{2} /$ year, with the smallest increase found on the plateau and the largest found in the snowbed, only values from the plateau were significantly different from the snowbed and the fell-field (Fig. 4). Mean individual age was ca. $50(\mathrm{SE}=3, \min .9$, max. 126) years for each community except for the snowbed, where individuals were significantly younger (mean $=14$ years old, $\mathrm{SE}=2$, $\min .=6, \max .=39$; MCTAKW, $P<0.05)$. Mean stem radial growth was $40 \mu \mathrm{m} /$ year in the heath, $64 \mu \mathrm{m} /$ year on the plateau, $74 \mu \mathrm{m} /$ year in the fell-field and $96 \mu \mathrm{m} /$ year in the snowbed, but only values from the heath were significantly different from the snowbed and fell-field (Fig. 4).

\section{Discussion}

Our study showed that Salix arctica might be responding rapidly to changing conditions in snowbed communities through successful reproduction, establishment and growth. However, in adjacent plant communities, it had a comparatively lower performance. Variability in the species growth and reproduction emphasises the influence of local abiotic and biotic factors and provide insight into the range of response that can be expected at the local landscape level.

\section{Salix arctica performance in the snowbed}

Plant community monitoring between 1997 and 2008 in the Zackenberg valley lowland indicated that Salix arctica cover did not change significantly in the plateau, the heath and the snowbed, the same plant communities sampled in this study (Schmidt, Kristensen et al. 2012). However, our results suggest that in the snowbed, compared to the three other plant communities, individuals are growing fast and producing a large number of seeds that are successfully establishing and maintaining themselves. Mean individual age in the snowbed was also much younger (ca. 14 years) than in the three other plant communities studied. This could be either attributed to a recent increase in recruitment or higher mortality of older individuals. However, the latter is unlikely since we observed fewer dead individuals in the snowbed, which remain in place after death, than at any other sites (N.B.-L., pers. obs.). It is yet unclear if shrubs such as the Arctic willow experience a decline or increase in growth with age (Myers-Smith, Hallinger et al. 2015). Detailed annual growth measures would be necessary to assess the specific effect of age on the annual growth of this species at this site. However, a qualitative assessment of the stem sections (Fig. 3) does suggest that the large growth measured in the snowbed is more than an artefact of the young age of the population. The absence of old individuals and the comparatively good plant performance indicated that this population is most probably expanding both clonally and sexually in response to recent increase in summer temperature and decline in snow cover (Schmidt, Kristensen et al. 2012) which is in accordance with studies that found snow cover to be the main climatic factor affecting plant productivity in the region (Buus-Hinkler et al. 2006). It appears that this response was not yet strong enough to be detected by Schmidt, Kristensen et al. (2012). This may not be surprising given that the mean age was 14 years; most current individuals would have established between 1995 and 2000 and must still have a marginal effect on the total plant cover. The current high performance of the Arctic willow in the snowbed may represent a transient stage and we could expect a decrease in plant performance if temperature continues to rise and spring snow cover declines, leading to lower soil moisture. In support of this hypothesis, BoulangerLapointe et al. (2014) demonstrated the effect of water limitation for a number of Arctic willow populations across the High Arctic and pulses in recruitment along the margin of retreating glaciers.

\section{Factors limiting recruitment and growth}

In High-Arctic Canada, higher reproductive effort was measured for $S$. arctica in mesic to wet habitats than in dry habitats (Klady et al. 2011). Our results point to similar conclusions even though differences in catkin density were not significant for all plant communities. Seedling occurrence followed the pattern in catkin density, indicating that a greater proportion of seeds fall in the vicinity of mother plants (Gage $\&$ Cooper 2005). Greater seedling establishment and survival has been found to occur in the shelter created by cushion plants (Polunin 1936; Griggs 1956). However, competition with Cassiope tetragona may have a major impact on establishment success. Cassiope tetragona may be limiting the Arctic willow growth as it has considerable amount of dead tissue attached to live plants, which constitute $>70 \%$ of plant above ground standing crop, thick and tight litter, as well as a relatively high canopy (ca. $10-15 \mathrm{~cm}$ ) compared to the surrounding vegetation (Nams $\&$ Freedman 1987). Release of secondary metabolites by $C$. tetragona may also have affected plant performance as they have been shown to inhibit growth of neighbouring species (Michelsen et al. 1995; Callaghan et al. 2004). We could infer that these factors cause competition for light and space and therefore explain the Low Arctic willow 
performance in the heath, since nutrient and moisture contents are not significantly different between the heath and the snowbed, the other plant community with high vegetation cover. Differences in burial time and sampling year for the nutrient analysis may have introduced discrepancies, but the values measured in the fell-field (the only plant community where soil nutrient was measured in 2010) do not appear to be outliers. Experimental studies in southern locations found that microtopographic relief favoured willow seed entrapment in depressions (Gage \& Cooper 2005). Hence, seedling density is positively related to the shelter effect of surrounding vegetation or, in barren habitats, sheltering microtopography. Interestingly, the only seedling observed on the plateau was found in the shelter created by a small $(<1 \mathrm{~cm})$ pebble. Seedling demography studies usually map seedlings to follow individuals through time (Wager 1938; Douglas 1995; Forbis 2003; Venn \& Morgan 2009). In this study, we developed a protocol that could be used to evaluate seedling density and survivorship over one field season. The growth scar method to age seedlings provided results without destructive sampling. It indicated that seedling mortality mostly occurred during the first year following establishment. The presence of withered seedlings on the fell-field suggested that at least some seedlings died in the first few weeks following germination, most probably due to insufficient soil moisture.

Grazing by large and small herbivores has been shown to significantly affect plant growth and reproductive success in the Arctic (Post \& Pederson 2008; Bêty et al. 2014). Previous food web studies using long-term biological monitoring data from Zackenberg demonstrated that muskox is the principal consumer of plant biomass and may ingest twice as much of the total plant production as other small herbivores, including insects, combined (Legagneux et al. 2014). If herbivores are to have an impact on the growth of the Arctic willow, we could hypothesize that the strongest competitive pressure would come from the muskox and depend on their selection of foraging sites. During the summer in the Zackenberg valley, muskoxen mainly forage in grasslands, fens and, to a lesser extent, snowbeds (Kristensen et al. 2011). Muskox densities at Zackenberg increase markedly through summer and early autumn to reach some of the highest values recorded for Arctic regions (Schmidt et al. 2015). During the winter, muskoxen often eat stems, terminal twigs and dormant buds of $S$. arctica in dry heaths with thin snow cover (Thing et al. 1987). As such, the plateau and the fell-field could be preferred for winter grazing while herbivory in the Cassiope heath is expected to be low as $C$. tetragona has among the lowest crude protein content and digestibility of common High-Arctic plants (Larter \& Nagy 2001). All things considered, herbivore activity may not be a dominant factor limiting growth and establishment of the Arctic willow in the Zackenberg valley since, among the four communities sampled, muskox activities are most important in the snowbed site, where the willow performance was highest. For this reason, our study lends more support to previous results that showed a positive impact of muskox foraging on the growth of S. arctica (Tolvanen et al. 2002).

Vegetation modelling using remote sensing tools is useful to determine trends that will affect the global climate system. However, thresholds and inflection points in those trends can only be found through a better understanding of the underlying ecosystem processes. In this study, we found that the Arctic willow is positively responding to increases in temperature and lengthening of the growing season only when water is abundant. If temperatures continue to increase, permanent snow patches will melt and soil moisture will decline and therefore temperature alone may not have a significant impact on plant productivity. On the other hand, our detailed study of reproductive success and growth suggests that coarse indicators, such as plant cover, might only detect change in plant performance years after they were initiated. Such lags in large-scale responses together with the confounding effect of biotic interactions that vary in strength across the Arctic will make forecasting effects of environmental change difficult, especially at the landscape scale.

\section{Conclusion}

Our study highlights the variability in growth and recruitment in relation to local biotic and abiotic factors. We found evidence that Salix arctica may be responding to reduction in snow cover through recruitment and growth in snowbed communities. It also highlights the importance of moisture availability and competition for light and space rather than herbivory and soil nutrients to explain plant performance across the plant communities studied. The very diverse response observed over a small area indicates that caution should be taken when comparing populations at large spatial scales as local factors introduce significant variability in plant performance.

\section{Acknowledgements}

Special thanks to Christian Bay for his advice and help in the field, Sylvie Ferland, Laurianne Bonin and Charlotte Kure Brandstrup for laboratory assistance, as well as Greg 
Henry for comments on the manuscript. This work was made possible by the financial support of the Fonds québécois de la recherche sur la nature et les technologies, the Northern Worlds initiative of the National Museum of Denmark, the Natural Sciences and Engineering Research Council of Canada, the Northern Scientific Training Program and ArcticNet-a Network of Centers of Excellence of Canada. The Arctic Research Centre, Aarhus University, provided logistical support for the fieldwork.

\section{References}

Aiken S.G., Dallwitz M.J., Consaul L.L., McJannet C.L., Gillespie L.J., Boles R.L., Argus G.W., Gillett J.M., Scott P.J., Elven R., LeBlanc M.C., Brysting A.K. \& Solstad H. 2007. Flora of the Canadian Arctic Archipelago: descriptions, illustrations, identification, and information retrieval. Ottawa: NRC Research Press, National Research Council of Canada. Accessed on the internet at nature.ca/aaflora/data/index. htm in October 2014

Bay C. 1998. Vegetation mapping of Zackenberg valley, northeast Greenland. Copenhagen: Danish Polar Center and Botanical Museum, University of Copenhagen.

Bêty J., Graham-Sauve M., Legagneux P., Cadieux M.C. \& Gauthier G. 2014. Fading indirect effects in a warming Arctic tundra. Current Zoology 60, 189-202.

Bliss L.C. \& Svoboda J. 1984. Plant communities and plant production in the western Queen Elizabeth Islands. Holarctic Ecology 7, 325-344.

Boulanger-Lapointe N., Lévesque E., Boudreau S., Henry G.H. \& Schmidt N.M. 2014. Population structure and dynamics of Arctic willow (Salix arctica) in the High Arctic. Journal of Biogeography 41, 1967-1978.

Buus-Hinkler J., Hansen B.U., Tamstorf M.P. \& Pedersen S.B. 2006. Snow-vegetation relations in a High Arctic ecosystem: inter-annual variability inferred from new monitoring and modeling concepts. Remote Sensing of Environment 105, 237-247.

Callaghan T.V., Bjorn L.O., Chernov Y., Chapin T., Christensen T.R., Huntley B., Ims R.A., Johansson M., Jolly D., Jonasson S., Matveyeva N., Panikov N., Oechel W., Shaver G., Elster J., Henttonen H., Laine K., Taulavuori K., Taulavuori E. \& Zockler C. 2004. Biodiversity, distributions and adaptations of arctic species in the context of environmental change. Ambio 33, 404-417.

Campioli M., Leblans N. \& Michelsen A. 2012. Stem secondary growth of tundra shrubs: impact of environmental factors and relationships with apical growth. Arctic Antarctic and Alpine Research 44, 16-25.

Carlsson B.A. \& Callaghan T.V. 1991. Positive plant interactions in tundra vegetation and the importance of shelter. Journal of Ecology 79, 973-983.

Chapin F.S., III, McGraw J.B. \& Shaver G.R. 1989. Competition causes regular spacing of alder in Alaskan shrub tundra. Oecologia 79, 412-416.
Chapin F.S., III, Shaver G.R., Giblin A.E., Nadelhoffer K.J. \& Laundre J.A. 1995. Response of Arctic tundra to experimental and observed changes in climate. Ecology 76, 694-711.

Cooper E.J. 2006. Reindeer grazing reduces seed and propagule bank in the High Arctic. Canadian Journal of Botany 84, $1740-1752$.

Dawson T.E. \& Bliss L.C. 1989. Patterns of water-use and the tissue water relations in the dioecious shrub, Salix arcticathe physiological-basis for habitat partitioning between the sexes. Oecologia 79, 332-343.

Densmore R. \& Zasada J. 1983. Seed dispersal and dormancy patterns in northern willows: ecological and evolutionary significance. Canadian Journal of Botany 61, 3207-3216.

Douglas D.A. 1995. Seed germination, seedling demography and growth of Salix setchelliana on glacial river gravel bars in Alaska. Canadian Journal of Botany 73, 673-679.

Douhovnikoff V., Goldsmith G.R., Tape K.D., Huang C., Sur N. \& Bret-Harte M.S. 2010. Clonal diversity in an expanding community of Arctic Salix spp. and a model for recruitment modes of Arctic plants. Arctic Antarctic and Alpine Research 42, 406-411.

Elberling B., Tamstorf M., Michelsen A., Arndal M.F., Sigsgaard C., Illeris L., Bay C., Hansen B.U., Christensen T.R., Hansen E.S., Jakobsen B.H. \& Beyens L. 2008. Soil and plant community-characteristics and dynamics at Zackenberg. Advances in Ecological Research 40, 223-248.

Elmendorf S., Henry G.H.R., Hollister R.D., Björk R.G., Bjorkman A.D., Callaghan T.V., Siegwart Collier L., Cooper E.J., Cornelissen J.H.C., Day T.A., Fosaa A.M., Gould W.A., Gretarsdottir J., Harte J., Hermanutz L., Hik D.S., Hofgaard A., Jarrad F., Jonsdottir I.S., Keuper F., Klanderud K., Klein J.A., Koh S., Kudo G., Lang S.I., Loewen V., May J.L., Mercado J., Michelsen A., Molau U., Myers-Smith I.H., Oberbauer S.F., Pieper S., Post E., Rixen C., Robinson C.H., Schmidt N.M., Shaver G.R., Stenström A., Tolvanen A., Totland Ø., Troxler T., Wahren C.H., Webber P.J., Welker J.M. \& Wookey P.A. 2012. Global assessment of experimental climate warming on tundra vegetation: heterogeneity over space and time. Ecological Letters 15, 164-175.

Elmendorf S., Henry G.H.R., Hollister R.D., Björk R.G., Boulanger-Lapointe N., Cooper E.J., Cornelissen J.H.C., Day T.A., Dorrepaal E., Elumeeva T.G., Gill M., Gould W.A., Harte J., Hik D.S., Hofgaard A., Johnson D.R., Johnstone J.F., Jónsdóttir I.S., Jorgenson J.C., Klanderud K., Klein J.A., Koh S., Kudo G., Lara M., Lévesque E., Magnússon B., May J.L., Mercado-Díaz J.L., Michelsen A., Molau U., Myers-Smith I.H., Oberbauer S.F., Onipchenko V.G., Rixen C., Schmidt N.M., Shaver G.R., Spasojevic M.J., Pórhallsdóttir P.E., Tolvanen A., Troxler T., Tweedie C.E., Villareal S., Wahren C.-H., Walker X., Webber P.J., Welker J.M. \& Wipf S. 2012. Plot-scale evidence of tundra vegetation change and links to recent summer warming. Nature Climate Change 2, 453-457.

Falk J.M., Schmidt N.M., Christensen T.R. \& Strom L. 2015. Large herbivore grazing affects the vegetation structure and greenhouse gas balance in a High Arctic mire. Environmental 
Research Letters 10, article no. 045001, doi: 10.1088/17489326/10/4/045001.

Farrer E.C., Ashton I.W., Knape J. \& Suding K.N. 2014. Separating direct and indirect effects of global change: a population dynamic modeling approach using readily available field data. Global Change Biology 20, 1238-1250.

Forbes B.C., Fauria M.M. \& Zetterberg P. 2010. Russian Arctic warming and "greening" are closely tracked by tundra shrub willows. Global Change Biology 16, 1542-1554.

Forbis T.A. 2003. Seedling demography in an alpine ecosystem. American Journal of Botany 90, 1197-1206.

Forchhammer M.C., Post E., Berg T.B.G., Hoye T.T. \& Schmidt N.M. 2005. Local-scale and short-term herbivore-plant spatial dynamics reflect influences of large-scale climate. Ecology 86, 2644-2651.

Gacitua G., Bay C., Pedersen M.R. \& Tamstorf M.P. 2013. Quantifying snow and vegetation interactions in the High Arctic based on ground penetrating radar (GPR). Arctic Antarctic and Alpine Research 45, 201-210.

Gage E.A. \& Cooper D.J. 2005. Patterns of willow seed dispersal, seed entrapment, and seedling establishment in a heavily browsed montane riparian ecosystem. Canadian Journal of Botany 83, 678-687.

Giraudoux P. 2013. Pgirmess: data analysis in ecology. R package version 1.5.8. Accessed on the internet at https:// cran.r-project.org/web/packages/pgirmess/index.html

Gold W.G. \& Bliss L.C. 1995. Water limitations and plant community development in a polar desert. Ecology 76, 1558-1568.

Griggs R.F. 1956. Competition and succession on a Rocky Mountain fellfield. Ecology 37, 8-20.

Hansen B.U., Sigsgaard C., Rasmussen L., Cappelen J., Hinkler J., Mernild S.H., Petersen D., Tamstorf M.P., Rasch M. \& Hasholt B. 2008. Present-day climate at Zackenberg. Advances in Ecological Research 40, 111-149.

Hassol S.J. 2004. Arctic climate impact assessment: impacts of a warming Arctic. Cambridge: Cambridge University Press.

Hinkler J., Birger U.H., Tamstorf M.P., Sigsgaard C. \& Petersen D. 2008. Snow and snow-cover in central northeast Greenland. Advances in Ecological Research 40, 175-195.

Jensen L.M., Christensen T.R. \& Schmidt N.M. 2014. Zackenberg ecological research operations. 19th annual report 2013. Roskilde: Danish Centre for Environment and Energy, Aarhus University.

Jones M.H. 1995. Experimental investigations into effects of climate change on High Arctic plants. PhD dissertation, University of Alberta, Edmonton.

Jones M.H., Macdonald S.E. \& Henry G.H.R. 1999. Sex- and habitat-specific responses of a High Arctic willow, Salix arctica, to experimental climate change. Oikos 87, 129-138.

Klady R.A., Henry G.H.R. \& Lemay V. 2011. Changes in High Arctic tundra plant reproduction in response to long-term experimental warming. Global Change Biology 17, 1611-1624.

Kristensen D., Kristensen E., Forchhammer M., Michelsen A. \& Schmidt N. 2011. Arctic herbivore diet can be inferred from stable carbon and nitrogen isotopes in C3 plants, faeces, and wool. Canadian Journal of Zoology 89, 892-899.
Larter N.C. \& Nagy J.A. 2001. Seasonal and annual variability in the quality of important forage plants on Banks Island, Canadian High Arctic. Applied Vegetation Science 4, 115-128.

Legagneux P., Gauthier G., Lecomte N., Schmidt N.M., Reid D., Cadieux M.C., Berteaux D., Bety J., Krebs C.J., Ims R.A., Yoccoz N.G., Morrison R.I.G., Leroux S.J., Loreau M. \& Gravel D. 2014. Arctic ecosystem structure and functioning shaped by climate and herbivore body size. Nature Climate Change 4, 379-383.

le Roux P.C., Lenoir J., Pellissier L., Wisz M.S. \& Luoto M. 2013. Horizontal, but not vertical, biotic interactions affect fine-scale plant distribution patterns in a low-energy system. Ecology 94, 671-682.

le Roux P.C. \& Luoto M. 2014. Earth surface processes drive the richness, composition and occurrence of plant species in an Arctic-alpine environment. Journal of Vegetation Science $25,45-54$

Lévesque E. 1996. Minimum area and cover-abundance scales as applied to polar desert vegetation. Arctic and Alpine Research 28, 156-162.

Michelsen A., Schmidt I.K., Jonasson S., Dighton J., Jones H.E. \& Callaghan T.V. 1995. Inhibition of growth, and effects on nutrient uptake on Arctic graminoids by leaf extractsallelopathy or resource competition between plants and microbes? Oecologia 103, 407-418.

Myers-Smith I.H., Elmendorf S.C., Beck P.S.A., Wilmking M., Hallinger M., Blok D., Tape K.D., Rayback S.A., MaciasFauria M., Forbes B.C., Speed J.D.M., Boulanger-Lapointe N., Rixen C., Lévesque E., Schmidt N.M., Baittinger C., Trant A.J., Hermanutz L., Siegwart Collier L., Dawes M.A., Lantz T., Weijers S., Jørgensen R.H., Buchwal A., Buras A., Naito A.T., Ravolainen V., Schaepman-Strub G., Wheeler J., Wipf S., Guay K., Hik D.S. \& Vellend M. 2015. Climate sensitivity of shrub growth across the tundra biome. Nature Climate Change 5, 887-891.

Myers-Smith I.H., Hallinger M., Blok D., Sass-Klaassen U., Rayback S.A., Weijers S., Trant A.J., Tape K.D., Naitoi A.T., Wipf S., Rixen C., Dawes M.A., Wheeler J.A., Buchwal A., Baittinger C., Macias-Fauria M., Forbes B.C., Lévesque E., Boulanger-Lapointe N., Beil I., Ravolainen V. \& Wilmking M. 2015. Methods for measuring Arctic and alpine shrub growth: a review. Earth-Science Reviews 140, 1-13.

Myers-Smith I.H., Hik D.S., Kennedy C., Cooley D., Johnstone J.F., Kenney A.J. \& Krebs C.J. 2011. Expansion of canopyforming willows over the twentieth century on Herschel Island, Yukon Territory, Canada. Ambio 40, 610-623.

Nams M.L.N. \& Freedman B. 1987. Ecology of heath communities dominated by Cassiope tetragona at Alexandra Fjord, Ellesmere Island. Holarctic Ecology 10, 22-32.

Olofsson J., Oksanen L., Callaghan T., Hulme P.E., Oksanen T. \& Suominen O. 2009. Herbivores inhibit climate-driven shrub expansion on the tundra. Global Change Biology 15, 2681-2693.

Olofsson J., Oksanen L., Oksanen T., Tuomi M., Hoset K.S., Virtanen R. \& Kyro K. 2014. Long-term experiments reveal strong interactions between lemmings and plants in the Fennoscandian highland tundra. Ecosystems 17, 606-615. 
Pajunen A.M., Oksanen J. \& Virtanen R. 2011. Impact of shrub canopies on understorey vegetation in western Eurasian tundra. Journal of Vegetation Science 22, 837-846.

Polunin N. 1936. Plant succession in Norwegian Lapland. Journal of Ecology 24, 372-391.

Porsild A. 1957. Illustrated flora of the Canadian Arctic Archipelago. Bulletin 146. Biological Series 50. Ottawa: Minister of Northern Affairs and National Ressources.

Porsild A.E. \& Cody W.J. 1980. Vascular plants of the continental Northwest Territories, Canada. Ottawa: National Museum of Canada.

Post E. \& Pedersen C. 2008. Opposing plant community responses to warming with and without herbivores. Proceedings of the National Academy of Sciences of the United States of America 105, 12353-12358.

Raup H.M. 1963. Turf hummocks in the Mesters Vig district, northeast Greenland. In: Proceedings of the International Permafrost Conference, 11-15 November, Lafayette, Indiana. Pp. 43-50. Washington, DC: National Academy of Sciences and National Research Council.

R Core Team. 2014. R: a language and environment for statistical computing, Version 3.1.1. Vienna: R Foundation for Statistical Computing.

Ropars P. \& Boudreau S. 2012. Shrub expansion at the foresttundra ecotone: spatial heterogeneity linked to local topography. Environmental Research Letters 7, article no. 015501, doi: http://dx.doi.org/10.1088/1748-9326/7/1/015501

Schmidt N.M., Baittinger C., Kollmann J. \& Forchhammer M.C. 2010. Consistent dendrochronological response of the dioecious Salix arctica to variation in local snow precipitation across gender and vegetation types. Arctic Antarctic Alpine Research 42, 471-475.

Schmidt N.M., Hansen L.H., Hansen J., Berg T.B. \& Meltofte H. 2012. BioBasis - conceptual design and sampling procedures of the biological programme of Zackenberg Basic. 15th edn. Roskilde: Department of Bioscience, University of Aarhus.

Schmidt N.M., Kristensen D.K., Michelsen A. \& Bay C. 2012. High Arctic plant community responses to a decade of ambient warming. Biodiversity 13, 191-199.

Schmidt N.M., Pedersen S.H., Mosbacher J.B. \& Hansen L.H. 2015. Long-term patterns of muskox (Ovibos moschatus) demographics in High Arctic Greenland. Polar Biology 38, 1667-1675.

Shaver G.R., Laundre J.A., Giblin A.E. \& Nadelhoffer K.J. 1996. Changes in live plant biomass, primary production and species composition along a riverside toposequence in Arctic Alaska, USA. Arctic and Alpine Research 28, 363-379.

Shevtsova A., Graae B.J., Jochum T., Milbau A., Kockelbergh F., Beyens L. \& Nijs I. 2009. Critical periods for impact of climate warming on early seedling establishment in Subarctic tundra. Global Change Biology 15, 2662-2680.
Spadavecchia L., Williams M., Bell R., Stoy P.C., Huntley B. \& van Wijk M.T. 2008. Topographic controls on the leaf area index and plant functional type of a tundra ecosystem. Journal of Ecology 96, 1238-1251.

Steltzer H., Hufbauer R.A., Welker J.M., Casalis M., Sullivan P.F. \& Chimner R. 2008. Frequent sexual reproduction and high intraspecific variation in Salix arctica: implications for a terrestrial feedback to climate change in the High Arctic. Journal of Geophysical Research-Biogeosciences 113, G03S10, doi: http://dx.doi.org/10.1029/2007JG000503

Stocker T.F., Qin D., Plattner G.-K., Tignor M., Allen S.K., Boschung J., Nauels A., Xia Y., Bex V. \& Midgley P.M. (eds.) 2013. Climate change 2013. The physical science basis. Contribution of Working Group I to the fifth assessment report of the Intergovernmental Panel on Climate Change. Cambridge: Cambridge University Press.

Sturm M., Racine C. \& Tape K. 2001. Increasing shrub abundance in the Arctic. Nature 411, 546-547.

Tamstorf M.P., Illeris L., Hansen B.U. \& Wisz M. 2007. Spectral measures and mixed models as valuable tools for investigating controls on land surface phenology in High Arctic Greenland. BMC Ecology 7(9), doi: http://dx.doi.org/10. 1186/1472-6785-7-9

Thing H., Klein D.R., Jingfors K. \& Holt S. 1987. Ecology of muskoxen in Jameson Land, northeast Greenland. Holarctic Ecology 10, 95-103.

Tolvanen A., Schroderus J. \& Henry G.H.R. 2002. Ageand stage-based bud demography of Salix arctica under contrasting muskox grazing pressure in the High Arctic. Evolutionary Ecology 15, 443-462.

Tremblay B., Lévesque E. \& Boudreau S. 2012. Recent expansion of erect shrubs in the Low Arctic: evidence from eastern Nunavik. Environmental Research Letters 7, article no. 035501, doi: http://dx.doi.org/10.1088/1748-9326/7/3/ 035501

Venn S.E. \& Morgan J.W. 2009. Patterns in alpine seedling emergence and establishment across a stress gradient of mountain summits in south-eastern Australia. Plant Ecology O Diversity 2, 5-16.

Wager H.G. 1938. Growth and survival of plants in the Arctic. Journal of Ecology 26, 390-410.

Walker M.D., Wahren C.H., Hollister R.D., Henry G.H.R., Ahlquist L.E., Alatalo J.M., Bret-Harte M.S., Calef M.P., Callaghan T.V., Carroll A.B., Epstein H.E., Jonsdottir I.S., Klein J.A., Magnusson B., Molau U., Oberbauer S.F., Rewa S.P., Robinson C.H., Shaver G.R., Suding K.N., Thompson C.C., Tolvanen A., Totland O., Turner P.L., Tweedie C.E., Webber P.J. \& Wookey P.A. 2006. Plant community responses to experimental warming across the tundra biome. Proceedings of the National Academy of Sciences of the United States of America 103, 1342-1346. 